Insignia Journal of International Relations

Vol. 6, No.1, April 2019, 13-29

P-ISSN: 2089-1962; E-ISSN: 2597-9868

\title{
Perbandingan Penegakan Demokrasi di Indonesia Pasca-Rezim Suharto dan Filipina Pasca-Rezim Marcos
}

\author{
Kisno Hadi \\ Fakultas Ilmu Sosial dan Politik, Universitas Kristen Palangka Raya \\ Email: kisno.hadi@yahoo.co.id
}

\begin{abstract}
Abstrak
Tulisan ini mendeskripsikan dan menganalisis perjalanan memperoleh demokrasi di dua negara yang pernah sama-sama mengalami rezim anti demokrasi yaitu Indonesia di bawah Suharto dan Filipina di bawah Marcos. Dua negara ini sama-sama mengalami rezim militeristik, namun setelah demokrasi berhasil diraih dan ditegakkan tetap saja terjadi kecenderungan-kecenderungan tindakan aktor politik hendak mengembalikan ke keadaan anti demokrasi seperti praktik pemerintahan yang tidak mencerminkan nilai-nilai demokrasi yaitu korupsi, politik oligarki, lemahnya penegakan hukum di berbagai bidang, hingga separatisme. Ada 3 hal penting yang disampaikan dalam tulisan ini, yaitu pertama, keadaan rezim militeristik yang menguasai kedua negara; kedua, latar belakang kejatuhan rezim militeristik dan diperolehnya sistem demokrasi dalam pengelolaan negara; dan ketiga, tantangan penegakan dan pelaksanaan demokrasi bagi kedua negara dalam politik masa kini. Tulisan ini merupakan hasil studi pustaka dengan metode deskriptif explanatory dan teknik analisis data kualitatif interpretatif. Temuan studi ini ialah Pertama, praktik demokrasi menunjukkan banyak hal baik seperti implementasi good governance dan pembangunan ekonomi melalui infrastruktur dan pajak, namun disertai munculnya masalah baru seperti menguatnya oligarki di pusat dan daerah di bidang politik dan ekonomi hingga membesarnya praktik korupsi pejabat negara. Kedua, ada perbedaan sikap politik kedua negara dalam rekonsiliasi dengan rezim masa lalu, Filipina dapat melupakan trauma politik masa lalu yakni aktor politik masa kini yang merupakan warisan rezim politik masa lalu bisa bekerjasama dan berkonsentrasi membangun bangsa dan negara ke depan tanpa saling fitnah dan kecurigaan. Sedangkan di Indonesia, terjadi sikap politik berbeda, di mana saling curiga dan fitnah yang sering dikaitkan dengan warisan politik masa lalu; Ketiga, kedua negara terus bekerja keras mencari model demokrasi yang cocok; dan Keempat, kedua negara mempunyai tugas besar dalam menegakkan demokrasi dengan bekerja keras menciptakan kesejahteraan bagi warga negara, penegakan hukum termasuk pemberantasan korupsi, pemberantasan narkoba, kerjasama luar negeri dan membina hubungan politik pusat dan daerah.
\end{abstract}

Kata kunci: Demokrasi, Militeristik, Negara, Perbandingan Politik, Politik Kontemporer

\begin{abstract}
This article describes and analyzes the journey of enforcement of democracy between Indonesia and Philipines which is occur after the end of regimes that tore both countries, i.e. by regime of Suharto in Indonesia and Marcos in Phillipines. But, the facts these countries still struggling to resolve tendencies that weaken democratization such as corruptions, oligarkhi of politics, weakness of law enforcement, separatism etc. For those reasons, author underlines three important things in this article to analyze problems, i.e., firstly, situation of regimes that control both countries; secondly, background of situation that overthrown the regimes and thirdly, the challenges of enforcement and implementation of democration for both countries in political situation today. This article is a library research that using descriptive explanatory method with qualitative interpretative data analitys. Finally, author find four results of the research, i.e. firstly, in practical of democracy, both countries display a good progress as a implementation of good governance and economic development e.g. in infrastructure and tax policy. But this situation raising new problems such as oligarchy strengthened in politics and economics sector both in national level and local regions level that result increase numbers of corruption of the rulers of government. Secondly, on political will between Indonesia and Philipines concerning of the reconciliation with the regime: Philipines decided to still involving actors of last
\end{abstract}


regime to develop the country; but Indonesia still in trauma with the regime, suspicious, hatred are dominated as a result of political tension. Thirdly, both contries are still on going process to find the appropriate of democracy model. And fourthly, Indonesia and Philipines are strive to create prosperity and welfare for their people on law enforcement including eradication of corruption, fighting drugs abuse, build cooperation with foreign country and harmonizing of political relation between national and regional level.

Keywords: Comparative Politics, Contemporary Politic, Democracy, Militeristic, State

\section{PENDAHULUAN}

Di panggung politik internasional, demokrasi telah mencapai status hegemoni. Hampir tidak ada sistem politik lain yang diwacanakan secara serius sebagai alternatif selain "demokrasi". Kalau sesuatu disebut "bukan demokrasi" maka sinonimnya adalah "tidak demokratis", dan penilaiannya sama dengan "tidak benar". Tidak demokratis berarti disebut tidak menghargai hak-hak politik yang merupakan esensi hak asasi manusia. Pemerintahan militeristik seperti Sudan atau Korea Utara saja mengklaim diri demokratis. Namun, kalau istilah yang sama dipakai untuk menggambarkan sistem politik di Swedia, Zimbabwe, Iran, Vietnam, dan Amerika Serikat, maka istilah itu tidak dapat dipakai tanpa terlebih dahulu bertanya "demokrasi macam apa?" Apa lagi konsep demokrasi yang sangat umum tanpa isi yang jelas, akan sulit diterapkan ke dalam tolok ukur dan rancangan aksi politik yang konkrit. Kekaburan konseptual demokrasi seperti demikian justru menghambat upaya-upaya menegakkan demokrasi di Indonesia pasca rezim Suharto tahun 1998 dan pasca rezim Marcos di Filipina tahun 1986.

Kekaburan konseptual demokrasi tidak berarti di Indonesia maupun di Filipina mengalami krisis intelektual maupun aktor politik, justru politik hari ini di kedua negara tersebut diwarnai banyak fenomena politik demokrasi oleh tindakan aktor politik, termasuk tindakan politik yang bercirikan anti demokrasi seperti korupsi, separatisme, penegakan hukum yang belum memuaskan, utang luar negeri yang masih tinggi, dan aktor oligarki warisan politik masa lalu masih mendominasi panggung politik nasional maupun lokal. Padahal rezim militeristik di kedua negara ini sudah lebih 20 tahun berakhir (Bradley \& Lubis, 1991: 79-80). Masalah ini menjadi pekerjaan besar kedua negara ini yakni bagaimana mencari dasar konseptual tentang demokrasi yang dapat menjadi titik tolak bagi upaya pendidikan politik dalam negeri untuk mendukung kemandirian bangsa dalam upaya meraih demokrasi yang sejati?

Tulisan ini hendak mendeskripsikan keadaan rezim militeristik yang menguasai kedua negara dan bagaimana sistem politik demokrasi berupaya ditegakkan dalam masa trasisi, serta tantangan penegakan dan pelaksanaan demokrasi bagi kedua negara dalam politik masa kini. Pentingnya tulisan ini dalam rangka, pertama, mengetahui sejauh mana dampak sistem politik militeristik dalam sebuah negara sehingga menjadi pelajaran penting dan tidak terulang kembali; kedua, untuk meluruskan jalan cita-cita demokrasi yang belakangan nampak menyimpang seperti korupsi yang masih merajalela dan oligarki politik yang sulit ditiadakan; dan ketiga, mengetahui perkembangan demokrasi atau dampak sistem politik demokrasi bagi kedua negara dalam politik masa kini. Kendati banyak masalah yang hampir sama terjadi pada kedua negara ini, tulisan ini hanya terfokus kepada oligarki politik warisan masa lalu yang masih menguasai politik di kedua negara ini.

Menelaah penjelasan tersebut di atas, maka muncul permasalahan penelitian, bagaimana perjalanan demokrasi di dua negara yang sama-sama pernah mengalami 
rezim otoriter ini? Filipina mengalami keruntuhan rezim Marcos pada hari Selasa 25 Februari 1986 dengan dilantiknya Cory Aquino menjadi Presiden Filipina pada hari itu juga, sementara Indonesia mengalami keruntuhan rezim Suharto pada hari Kamis 21 Mei 1998 dengan dilantiknya B. J. Habibie menjadi Presiden RI di hari yang sama. Kendati pun Filipina telah mengalami demokrasi 12 tahun lebih awal ketimbang Indonesia, sesungguhnya yang terjerat lebih lama dalam rezim militeristik adalah Indonesia, yaitu dalam rentang 32 tahun, sementara Filipina 21 tahun. Untuk itu, menarik menganalisis proses demokrasi di kedua negara ini. Pertanyaannya ialah, pertama, bagaimana akar keruntuhan rezim militeristik di Filipina dan Indonesia? Kedua, bagaimana perjalanan pembangunan demokrasi di Filipina pasca Marcos dan di Indonesia pasca Suharto? Ketiga, bagaimana demokrasi di kedua negara hari ini?

\section{Kajian Literatur}

Hampir sama mengemuka baik di Filipina maupun Indonesia hingga hari ini dalam konteks politik domestik kedua negara, ialah kemunculan oligarki politik warisan masa lalu yang menguasai politik nasional maupun politik lokal. Fenomena ini diamati Jhon T. Sidel mengenai perpolitikan lokal di Filipina Selatan yang ia sebut politik "bosisme". Teori bosisme lahir dari kritik Sidel terhadap pendekatan "orang kuat di tingkat lokal" (local strongman) yang dikemukakan Joel S. Migdal. Dalam studinya tentang Filipina, Sidel memakai teori ini untuk menjelaskan "orang-orang kuat" dalam masyarakat dan politik Filipina, di mana orang-orang kuat justru lahir karena kekuatan negara, dan karena kemampuannya memanfaatkan negara.

Sidel menafikan pendapat bahwa orang kuat lahir sebagai refleksi dari kekuatan masyarakat dan ketahanan elite tradisional atau oligarki regional. Dia malah melihat watak negara yang kuat dikendalikan oleh jejaring "bos". Bos-bos inilah yang memanipulasi negara sehingga memiliki kekuatan dan mampu melakukan penetrasi ke dalam masyarakat, mengatur hubungan-hubungan sosial, dan mengeksploitasi sumber-sumber daya alam. Pada akhirnya, negara pemangsa (predator) yang kuat itu dipakai oleh para bos untuk menekan massa rakyat. Negara seperti ini menurut pemikiran Marxian telah menjadi arena atau bahkan "predator" yang siap memangsa siapa pun yang tidak memiliki posisi strategis serta mereka yang mengancam kekuasaan negara. Lewat negara kekuasaan politik diperoleh, dan melalui negara pula segala kompensasi ekonomis bisa didapatkan (Supriatma, 2009: 6-7). Tapi bila melihat fenomena politik khas Asia, pengaruh oligarki tradisional maupun regional tidak bisa dikesampingkan dalam melahirkan orangorang kuat yang menguasai politik. Justru kekuatan mereka tetap eksis karena jejaring oligarki yang diwarisi dari politik masa lalu masih kuat.

Kemunculan Imelda Marcos, istri mendiang Presiden Marcos, misalnya, yang sampai tahun 2016 masih menjadi anggota Kongres, atau anaknya Ferdinand "Bongbong" Marcos Jr juga pernah menduduki posisi penting di Senat dan mencalonkan diri menjadi Wakil Presiden tahun 2016, harus dipandang sebagai kekuatan oligarki sebagai penyokong mereka. Kemudian Presiden Filipina ke 13 Joseph Estrada memiliki putra bernama Jinggoy Estrada dan J. V. Ejercito Estrada yang menjadi Senator dan Walikota San Juan City di Metro Manila. Di seluruh wilayah Filipina terdapat 170 dinasti politik dan lebih $90 \%$ dari seluruh provinsi di Filipina memiliki paling tidak satu dinasti politik. Di ranah politik nasional, sejak Rodrigo Duterte menjadi Presiden pertengahan Juni 2016 terdapat 13 Walikota dan Wakil yang tewas tertembak dengan dalih terlibat jaringan narkoba (Tempo, 2018). Realita tersebut jelas sebagai wujud penyimpangan dari demokrasi sebagaimana diperjuangkan 
selepas Marcos, bahkan orang kuat seperti ini memanfaatkan negara untuk eksis dan meraih cita-cita.

Di Indonesia, studi tentang eksistensi orang kuat dan oligarki antara lain dilakukan oleh Boni Hargens di Manggarai Barat, NTT, mengenai kekuatan premanisme dalam membekingi bos-bos lokal dan orang kuat daerah seperti elit politik lokal, pejabat birokrat, dan pengusaha. Keberlangsungan monopoli kekuasaan di tingkat lokal cenderung awet karena adanya persekongkolan di kalangan bos lokal terutama antara tokoh partai politik, pengusaha dan pejabat birokrat. Kondisi ini membawa pada kondisi, pertama, kekuasaan masih dipahami secara tradisional sebagai sesuatu yang lahir dari diri pemimpin, kekuasaan dipercayai adalah sesuatu yang inheren di dalam diri elit; kedua, demokrasi lokal menghadapi kerumitan yang serius dalam hal pembangunan dialog; ketiga, konflik pemerintah dengan masyarakat sipil seringkali direkayasa menjadi konflik antar kelompok dalam masyarakat (Hargens, 2009). Hampir semua daerah di Indonesia pasca regulasi desentralisasi tahun 1999 mengalami hal seperti yang terjadi di Manggarai (Bernidus, 2012: 38). Fenomena dibengkoknya makna dan substansi demokrasi terjadi di Banten melalui kekuasaan keluarga Gubernur Atut, atau keluarga Limpo di Provinsi Sulawesi Selatan, di mana mereka menguasai struktur politik dan ekonomi lokal (Purwaningsih, 2015). Di Bengkulu Gubernur Zomi Zola yang ditangkap KPK karena kasus korupsi, mewarisi kekuasaan ayahnya sebagai gubernur sebelumnya. Di Kalimantan, pengusaha batu bara, pengusaha $\mathrm{HPH}$, dan pengusaha kelapa sawit yang memperoleh eksistensi sejak masa Orde Baru, kini menguasai struktur politik dan ekonomi (Sompa, 2016). Di tingkat nasional tidak jauh berbeda, oligarki politik Sukarno masih sangat besar perannya melalui Megawati dalam pemerintahan Jokowi. Sementara Prabowo
Subianto yang merupakan bekas menantu Suharto terus menerus hendak menjadi presiden. Bahkan SBY yang sudah pernah berkuasa selama 10 tahun hendak lagi mengambil kekuasaan melalui peran oligarki anak-anaknya.

\section{Metode Penelitian}

Tulisan ini diangkat dari hasil penelitian menggunakan metode deskriptif explanatory yakni kombinasi antara penelitian deskriptif dan explanatory. Penelitian deskriptif menjawab pertanyaan "apa", sedangkan eksplanasi menjawab pertanyaan "mengapa" dan "bagaimana". Teknik analisis data secara kualitatif interpretatif, yaitu mengangkat secara ideografis berbagai fenomena dan realitas sosial, teori yang dihasilkan mendapatkan pijakan yang kuat pada realitas, bersifat kontekstual dan historis (Somantri, 2005: 64). Sumber data studi ini ialah data pustaka dengan memanfaatkan berbagai literatur tertulis seperti buku, majalah, jurnal ilmiah, berita koran, media internet. Studi pustaka dilakukan dalam masa bulan September sampai Desember 2018, dengan dilakukan berbagai penyempurnaan.

\section{PEMBAHASAN \\ Peralihan Rezim Otoriter ke Demokrasi}

Teori transisi ke demokrasi yang dibangun Guillermo O'Donnell, Philippe C. Schmitter, dan Laurance Whitehead (1993: 13-37), menarik disimak untuk mendiskusikan fenomena yang terjadi di Filipina dan Indonesia. Ketiganya menjelaskan transisi demokrasi di Amerika Latin dan Eropa Selatan menggunakan perspektif perbandingan politik. Hal yang paling fundamental ialah mengalihkan perhatian dari penggambaran dasar tentang demokrasi ke perhatian yang lebih luas, yang dilakukan dengan menganalisis proses konstitusi, legitimasi kekuasaan, hingga berkaitan dengan fenomena politik modern yaitu seperti pemilihan langsung atau tidak langsung dalam pengambilan keputusan, konsep dan implementasi budaya politik 
dalam demokratisasi, rezim-rezim politik otoriter yang menghambat demokrasi, hingga alasan kebangkrutan dan menumpuknya utang suatu negara. Modernisasi sebagai basis pertumbuhan budaya, pengaruh agama-agama seperti Katolik, Kristen, Budha dan Islam bagi suatu sistem politik sebuah negara tidak dapat diabaikan. Itu sebabnya, kenapa pembangunan ekonomi kemudian bertransformasi dari tidak sekadar menghubungkan peran kapitalis dengan demokrasi tetapi pembangunan ekonomi dapat mengubah demokrasi menjadi alat dalam jangka panjang untuk membangun negara. Walaupun demokrasi diketahui merupakan karakteristik kapitalisme, namun diakui bahwa demokrasi tetap memiliki korelasi signifikan dengan pembangunan.

Peristiwa demokratisasi di Amerika Latin dan pembandingnya negara di Eropa Selatan, dijadikan dasar pendapat bahwa betapa demokrasi, pembangunan ekonomi, dan gejolak politik lokal yang ditimbulkan oleh rezim politik yang berkuasa saling memiliki keterkaitan. Ciri-ciri domestik Amerika Latin berbeda bahkan dalam aspek penting bertentangan dengan kondisi yang ada di Eropa Selatan yaitu bahwa rezim otoriter di Amerika Latin muncul lebih dulu dibanding rezim otoriter di Eropa Selatan, sementara yang memperlihatkan persamaan bahwa demokratisasi muncul setelah negara dikuasai rezim otoriter yang didukung birokrasi pemerintah. Perbedaan paling menonjol antara kasus Amerika Latin dan sebagian besar kasus Eropa Selatan ialah pertama, peran sentral yang dimainkan militer di mana tingginya derajat militerisasi meningkatkan kesulitan untuk transisi; kedua, demokrasi politik di Amerika Latin bersifat mendua di mana di Amerika Latin demokrasi politik diidentifikasikan oleh partai politik berhaluan kiri dan populis sebagai sebuah mekanisme penghambat bagi pengikutnya dan manipulasi aspirasi daripada sebagai sebuah tatanan kelembagaan yang dapat dipertanggungjawabkan seperti perwakilan, pengolahan, dan akhirnya pemenuhan aspirasi; ketiga, faktor ekonomi lebih menguntungkan bagi demokrasi di Eropa Selatan daripada Amerika Latin, ini misalnya terkait kebijakan-kebijakan sosial, ekonomi dan pendidikan cenderung mundur di Amerika Latin dibandingkan di Eropa Selatan. Rezim pemerintahan sebelumnya juga tidak mampu menangani ketimpangan yang dituntut secara ekstrim dalam menangani permasalah tersebut ditambah krisis ekonomi luar biasa dan utang luar negeri yang besar; keempat, jalur pakta-pakta politik dan ekonomi yang resmi dan tertulis sebagai alat transisional di Amerika Latin bersifat tidak lazim yang membedakannya dengan di Eropa Selatan yang cukup konvensional digunakan.

Argumen pentingnya di sini ialah negara yang gejolak politiknya labil semisal jauhnya peran militer dalam pembangunan negara dapat mengarahkan negara tersebut mengalami kemunduran dalam kebijakan sosial, pembangunan ekonomi hingga pendidikan, yang justru menonjol ialah peranan militer dalam ranah publik, kekerasan politik yang terus menerus terjadi hingga mengarah ke revolusi dengan diiringi menumpuknya utang negara. Sementara itu, bagi negara yang peran militernya tidak terlalu jauh dalam pembangunan negara dapat memperlihatkan bahwa konstitusi, legitimasi kekuasaan, serta peralihan kekuasaan dapat berlangsung secara demokratis dan damai tanpa ada pertumpahan darah. Bahkan tanda-tanda menuju demokrasi dapat diperlihatkan di mana demokrasi dapat berdampingan secara baik dengan pembangunan ekonomi. Pembangunan ekonomi yang baik dapat menjadikan demokrasi sebagai alat bagi pembangunan negara. Dengan demikian dapat dilihat apakah kasus Indonesia dengan Filipina akan sama seperti kasus transisi rezim di Amerika Latin dan Eropa Selatan tersebut. 


\section{Studi Kasus Indonesia}

Di masa pemerintahan Orde Baru dikenal istilah executive heavy di mana Suharto sebagai figur sentral dalam pemerintahan dapat menguasai dan mengendalikan legislatif. Namun pasca Orde Baru sekarang malah sebaliknya dikenal istilah legislative heavy di mana justru lembaga legislatif yang memegang peranan penting dalam pemerintahan. Indonesia tidaklah murni menganut sistem presidensial, karena dalam beberapa hal keputusan eksekutif baik di pusat maupun daerah mesti mendapat persetujuan legislatif, bahkan secara bersama-sama eksekutif dan legislatif dapat menyusun undang-undang atau peraturan daerah, yang menandakan ada unsur parlementer dalam sistem pemerintahan Indonesia. Ahliahli Indonesia menggunakan terminologi yang berbeda untuk menamakan sistem pemerintahan yang khas Indonesia ini. Ismail Suny menyebutnya Sistem QuasiPresidensial, Padmo Wahono menamakannya Sistem Mandataris, dan Azhary menamakannya Sistem MPR. Dalam klasifikasi Verney, sistem yang mengandung karakteristik sistem presidensial dan parlementer ini disebut sistem SemiPresidensial. Sejauh ini, sistem pemerintahan demokratis model Indonesia ini sesuai ciri-ciri sistem semi-presidensial dalam klasifikasi Verney (Effendi, 2010: 24). Indonesia merupakan negara kepulauan dengan jumlah 17.000 pulau, jumlah penduduk 320 juta jiwa lebih, menganut bentuk pemerintahan republik dengan bentuk negara kesatuan.

Atas dasar itu, ada kekhawatiran Suharto bila Indonesia tidak diperintah secara kuat, maka dapat menimbulkan disintegrasi. Kepemimpinan Suharto dikerahkan untuk menciptakan sistem politik berbasis negara kuat yang mengintegrasikan negara dengan masyarakat sipil serta penguasa dengan rakyat sebagaimana konsep negara integralis. ${ }^{1}$ Segenap kekuatan politik seperti militer, birokrat, politisi sipil di parlemen, dan kaum pengusaha dikerahkan dan dikontrol untuk tunduk kepada keputusan eksekutif. Fungsi politik legislatif seperti legislasi, penganggaran, dan pengawasan praktis tidak terjadi. Saat itu pemerintah Orde Baru mengagungkan stabilitas politik berkelanjutan serta pertumbuhan ekonomi tinggi, sehingga potensi konflik politik antara eksekutif dengan lembaga negara lainnya maupun kekuatan dalam masyarakat diminimalisir.

Konstruksi politik tersebut dapat bertahan hingga 32 tahun berkat siasat politik Orde Baru yang oleh A.S. Hikam disebut "politik depolitisasi" (Hikam, 1999: 87-88), atau oleh William Liddle disebut "politik terkontrol" (Liddle, 1999: 39-44). Dalam ruang politik seperti demikian, relasi politik pemerintah dengan legislatif memang terjadi, tetapi relasi kepura-puraan tanpa nilai demokrasi, yang dimotori Golkar sebagai partai pemerintah di legislatif, dan menguasai legislatif dari pemilu ke pemilu. Pun demikian dengan pihak oposisi yang sarat kepura-puraan, karena partai politik oposisi juga menghendaki pembagian kue kekuasaan dalam pemerintahan meski dalam jumlah terbatas. Semua kebijakan politik di legislatif tergantung arahan dari eksekutif, baik bagi partai koalisi maupun oposisi.

\footnotetext{
1 Konsep negara integralis bagi Indonesia pernah diperdebatkan dalam sidang Panitia Persiapan Kemerdekaan Indonesia (PPKI) 31 Mei 1945 untuk menentukan konstitusi yang tepat bagi Indonesia merdeka. Raden Supomo dan beberapa orang dari golongan integralis menghendaki konsep "negara integralistik" menjadi prinsip UUD 1945. Tapi kehendak tersebut gagal. Orde Baru kemudian membangkitkan kembali konsep negara integralis untuk menjustifikasi hukum yang memaksa semua organisasi sosial dan politik termasuk lembaga legislatif untuk tunduk di bawah kendali eksekutif. Lihat, Simon Philpott. Meruntuhkan Indonesia: Politik Postkolonial dan Otoritarianisme, (Yogyakarta: LKiS, 2003), hal. 243. Lihat juga David Bourchier. "Kisah Adat Dalam Imajinasi Politik Indonesia dan Kebangkitan Masa Kini", dalam Jamie S. Davidson, David Henley dan Sandra Moniaga (Ed.). Adat Dalam Politik Indonesia, 129-130. Jakarta: Yayasan Obor Indonesia dan KITLV-Jakarta, 2010.
} 
Soeharto berkuasa di Indonesia selama 32 tahun. Gaya kepemimpinannya dianggap otoriter karena banyak sekali manipulasi, pengebirian DPR, korupsi dan semua perintah dan keinginannya selalu terpenuhi. Semua elemen dan lembaga negara tunduk di bawah kekuasaannya. Tidak ada yang berani mengkritik atau melawan karena bisa ditangkap dan dijeblos ke penjara. Suharto membangun basis kekuasaannya dengan ditopang oleh apa yang disebut sebagai ABG yakni ABRI (terutama TNI-AD), Birokrasi dan Golkar. Pemilu pun dimanipulasi agar Golkar selalu menang. Partai politik difusi sehingga hanya ada dua partai ditambah satu Golongan Karya yang dapat ikut Pemilu. Lalu dalam pemilihan Presiden oleh MPR dikondisikan agar Suharto mesti menang. Pada tiga dasawarsa, pembangunan yang dirancangnya dinilai berhasil namun ada sebagian pihak yang mengatakan keberhasilan tersebut bersifat semu dan kamuflase.

Sebagai pemimpin Negara, harus diakui Suharto mampu menyelenggarakan pemerintahan di atas fondasi stabilitas politik dan keamanan serta pemerataan ekonomi, namun dalam berbagai kebijakannya banyak kekeliruan yang sekaligus menjadi ciri khas kepemimpinannya, yaitu diantaranya:

> Menurut Riswanda Imawan, ciri khas kepemimpinan Suharto ialah (1) membangun sistem politik monolitik yang sebenarnya tidak sesuai dengan ciri heterogenitas bangsa Indonesia, tidak diperbolehkan adanya perbedaan pendapat dan hak penguasa untuk memonopoli interpretasi atas hukum dan perundang-undangan yang berlaku; (2) pembatasan jumlah partai politik yang sebenarnya bertolak belakang dengan ide modernisasi (pembangunan ekonomi) yang justru dijadikan pilar kekuasaan; (3) politisasi birokrasi yang justru menguatkan sifat alamiah birokrasi yang otoriter; (4) membangun klientelisme ekonomi melalui praktik korupsi antara birokrasi pemerintah dan pihak kekuatan ekonomi swasta; (5) melakukan represi ideologis serta penggunaan wacana otoriter secara eksesif sehingga memunculkan ketakutan politik pada tataran masyarakat; dan (6) memanipulasi simbol-simbol kultural sehingga rakyat memandang penguasa sebagai makhluk yang paling arif, bijaksana, tanpa cacat, serta tidak perlu dikontrol secara demokratis. Orde Baru juga memiliki motto Trilogi Pembangunan yakni stabilitas, pemerataan, dan pertumbuhan ekonomi (Imawan, 2000: 266-267)).

Menurut Mochtar Mas'oed ciri khas kepemimpinan Suharto ialah (1) rezim Orde Baru dipimpin oleh militer sebagai suatu lembaga bekerjasama dengan para "teknokrat" sipil; (2) beberapa perusahaan besar yang mempunyai hubungan khusus dengan negara dan kapitalis internasional mendominasi perekonomian Indonesia; (3) pembuatan kebijaksanaan yang teknokratikbiroktatik; (4) massa dimobilisasikan; (5) tindakan-tindakan represif untuk mengendalikan oposisi; dan (6) kantor kepresidenan yang otonom, terpisah dari lembaga-lembaga birokrasi lainnya (Mas'oed, 1989: 204-209).

Kekuasaan Soeharto ditopang dengan membangun sistem kekuasaan sentralistik, feodalis, dan otoriter. Kebijakan-kebijakan nasional sepenuhnya di bawah pengaruh Presiden, bahkan DPR-MPR ditentukan oleh Soeharto secara langsung ataupun tidak, hal ini membuat langkah Soeharto mulus menjadi Presiden selama 32 tahun.

Suharto pada dasarnya tidak bekerja sendiri dan tidak berpikir sendiri, ia juga dikelilingi oleh orang-orang di sekitarnya, mulai keluarga hingga kronikroninya. Peranan Ibu Negara Tien Suharto, hingga anak-anaknya adalah faktor penting bagi Suharto dalam menentukan kebijakan negara. 
Di dua tahun akhir kepemimpinannya terjadi pergolakan yang menuntutnya mundur. Akhirnya, Suharto berhasil dilengserkan pada tanggal 21 Mei 1998. Mundurnya Suharto sebagai presiden terutama karena, pertama, semua menteri Kabinet Pelita VII yang dibentuk pasca Pemilu 1997 mengundurkan diri dari jabatan masing-masing dan memilih tidak lagi berpihak kepada Suharto; kedua, demonstrasi mahasiswa dan rakyat besarbesaran terjadi di hampir seluruh wilayah ibukota termasuk di Yogyakarta, Surabaya, Makassar, Medan, Kalimantan, dll; ketiga, kerusuhan yang melanda ibukota disertai aksi pembakaran, pembunuhan, penculikan, penjarahan dan aksi kriminal lainnya melanda hampir di seluruh wilayah ibukota Jakarta. Banyak darah dan air mata anak negeri tumpah dalam perjuangan menumbangkan Suharto, bahkan hingga sekarang ada beberapa aktivis yang hilang dan belum ditemukan keberadaannya. Peristiwa mundurnya Suharto dikenal sebagai Peristiwa Mei 1998.

Kejatuhan Suharto bermula dari krisis ekonomi yang terjadi mulai Oktober 1997, yang mana krisis ini sudah melanda Asia sejak bulan Juni di tahun yang sama dengan terjadinya devaluasi Bath Thailand, dan efek difusi yang luar biasa menimbulkan kepanikan negara-negara tetangga seperti Indonesia, Filipina, Korea Selatan, Hongkong, Taiwan dan Singapura. Kepanikan ini terjadi karena masyarakat di negara-negara tersebut tidak percaya dengan mata uang nasional, dan ramairamai mencari dolar AS. Kondisi ini memperburuk ketidakpercayaan terhadap pemerintah, sehingga mempercepat memburuknya perekonomian negaranegara tersebut termasuk Indonesia. Dari lima negara Asia yang terdampak krisis ekonomi, Indonesia berada dalam kondisi yang paling buruk, sehingga membuka lebih banyak kebobrokan ekonomi yang dibangun pemerintahan Suharto. Kondisi tersebut mengundang aksi kolektif demonstrasi mahasiswa mulai akhir tahun 1997 yang menghendaki reformasi total terhadap rezim Orde Baru yang dilanda krisis dengan target maksimal demokratisasi yakni "pemerintahan bebas KKN" dan "penghapusan Dwifungsi ABRI", serta target minimal "menurunkan Suharto". Aksi koletif ini pecah sampai menjelang Sidang Umum MPR bulan Maret 1998 di berbagai kota seperti Jakarta, Bandung, Yogyakarta, Semarang, Padang, Manado, Ujung Pandang, Solo, Denpasar dan kota-kota kecil lainnya. Di Yogyakarta, tepatnya di UGM, aksi kolektif mahasiswa melibatkan 30.000 orang yang lantang menolak pengangkatan kembali Suharto menjadi presiden ke-7 Indonesia. Setelah Suharto diangkat kembali menjadi presiden dalam SU MPR bulan Maret 1998, aksi koletif mahasiswa semakin besar sampai bulan April dan Mei 1998 yang menyebar di seluruh kota di Indonesia sampai ke Jayapura, Kupang, dan Medan. Sebagian aksi ini menempuh jalan damai dengan tidak terjadi bentrok dengan aparat keamanan, namun sebagian lagi menempuh jalan kekerasan. Tercatat antara 1 Maret sampai 2 Mei 1998, terjadi benturan fisik dengan aparat keamanan di 14 kota di Jawa, Sumatra, Bali dan Lombok. Di Jakarta, pada 12 Mei terjadi "Tragedi Trisakti" yang menewaskan 4 orang mahasiwa Universitas Trisakti karena tertembak aparat keamanan, bahkan diikuti oleh serangkaian kerusuhan besar-besaran, dengan korban jiwa, material, penculikan, dan pemerkosaan yang tidak sedikit (Eko, 2003: 210-238).

Pandangan lain mengatakan, kejatuhan Suharto juga disebabkan oleh akumulasi ketidakpuasan mahasiswa, LSM, praktisi, berbagai elemen bangsa lainnya karena menilai Suharto telah menjadi penguasa yang korup, bertindak sewenangwenang, berdiri di atas hukum, serta tingginya praktik korupsi, kolusi dan nepotisme yang menyebabkan biaya inefisiensi dalam perekonomian. Akibatnya, muncul meluasnya gerakan demonstrasi 
pro demokrasi yang menuntut penurunan Suharto dari panggung kekuasaan. Pucak gerakan tersebut pada tanggal 20 Mei 1998, di mana kabarnya Suharto menonton gerakan demonstrasi tersebut dari televisi di Istana Kepresidenan. Melihat besarnya gerakan tersebut, maka atas inisiatif sendiri dan didukung oleh adanya surat pernyataan pengunduran diri sejumlah menteri dalam kabinet Suharto, maka keesokan harinya, pada tanggal 21 Mei 1998 bertempat Istana Kepresidenan, Suharto mengumumkan pengunduran dirinya, dan di saat bersamaan dilaksanakan penyerahan kekuasaan kepada Wapres Habibie. Habibie dilantik menjadi Presiden mengganti Suharto oleh Ketua Mahkamah Agung yang dihadiri oleh kalangan terbatas, yakni mereka yang masih setia kepada Suharto sampai detik-detik pengunduran diri Suharto (Sahdan, 2004: 9-10).

Gaya feodalisme Orde Baru menyisakan nilai dalam tradisi elit yang feodalistik. Sampai sekarang, di banyak daerah di Indonesia banyak elit dari kalangan oligarki politik menjadi gubernur, bupati, walikota, ataupun camat (Champbell-Nelson, 2012). Pasca Orde Baru, militer memang menyingkir dari politik bahkan tidak mengambil alih kekuasaan tatkala terjadi kekacauan dan tunduk di bawah supremasi sipil. Akan tetapi seperti sudah disampaikan di bagian awal, banyak terjadi anomali demokrasi seperti korupsi yang dulu di masa Orde Baru terpusat di Jakarta sekarang malah menyebar ke daerah, Pilkada langsung yang dikuasai oligarki politik penguasa dan pengusaha, penegakan hukum yang masih lemah, separatisme di Aceh dan Papua sehingga harus diberi otonomi khusus pada tahun 2001, hingga booming pemekaran daerah yang dilakukan sekelompok elit lokal yang tidak kebagian kekuasaan lantas mencari sumber kekuasaan lain yakni memekarkan daerah.

Bahkan justru pasca keruntuhan Orde Baru muncul banyak kekacauan di Indonesia seperti kerusuhan antar etnik di banyak daerah, kerusuhan antar agama, separatis di Aceh dan Papua yang membuahkan Undang-undang otonomi khusus, kebangkitan etnik masyarakat lokal, dll. Oleh Klinken, pasca Orde Baru disebut sebagai era penegasan identitas yang cukup mengejutkan sekaligus dilematis. Mengejutkan karena pasca Orde Baru adalah era desentralisasi politik dan pemerintahan digalakkan, di mana proses desentralisasi dikonsepkan oleh para perumusnya untuk efisiensi administrasi pemerintahan modern sekaligus menghadirkan demokrasi di tingkat lokal, sedangkan kebangkitan komunitarian tidak pernah diperhitungkan sebelumnya tetapi malah menjadi bagian penting dari desentralisasi. Dilematis karena persoalan kebangkitan identitas berarti kebangkitan simbol-simbol kekuasaan sebelum republik ini berdiri yang merepresentasikan feodalisme (Klinken, 2010: 166). Di pusat, pemerintahan tak juga kunjung stabil dan belum terkonsolidasi dengan baik. Intinya, pasca keruntuhan Orde Baru demokrasi tidak juga terkonsolidasi secara baik dan mantap sehingga sangat rentan bagi kemunculan kembali tindakan represif dari negara.

\section{Studi Kasus Filipina}

Filipina adalah sebuah negara republik di Asia Tenggara, sebelah utara Indonesia dan Malaysia. Filipina merupakan negara kepulauan memiliki 7.107 pulau. Negara ini mendapat nama Filipina setelah diperintah penguasa Spanyol, Raja Felipe II. Setelah Perang Spanyol-Amerika tahun 1898, Filipina diperintah Amerika Serikat. Filipina kemudian menjadi negara persemakmuran di bawah Amerika Serikat sejak tahun 1935. Pada periode Persemakmuran dipotong Perang Dunia II, Filipina berada di bawah pendudukan militer Jepang. Filipina akhirnya memperoleh kemerdekaan (de facto) pada 4 Juli 1946. Filipina menganut sistem pemerintah parlementer, dan negara ditata dengan bentuk republik. Presiden berfungsi 
sebagai kepala negara, kepala pemerintahan dan panglima tertinggi angkatan bersenjata. Kabinet atau Dewan Menteri sebagai kekuasaan eksekutif dengan dikepalai seorang Perdana Menteri. Majelis Nasional sebagai pemegang kekuasan legislatif. Sedangkan kekuasaan yudikatif dipegang oleh Mahkamah Agung yang memiliki seorang Ketua Mahkamah Agung sebagai kepalanya dan 14 Hakim Agung, semuanya ditunjuk oleh presiden.

Presiden Filipina dipilih dalam pemilu untuk masa jabatan 6 tahun, dan memilih serta mengepalai kabinet. Dewan legislatif Filipina mempunyai dua kamar kongres yang terdiri dari Senat (24 orang senator) menjabat selama 6 tahun dan Dewan Perwakilan (tidak lebih dari 250 orang anggota kongres) menjabat selama 3 tahun. Dalam pembangunan ekonomi strategi ialah peningkatan pembangunan infrastruktur, merombak sistem pajak untuk menambah pendapatan pemerintah, juga deregulasi dan penswastaan ekonomi, dan meningkatkan integrasi perdagangan di wilayah sekitar. Prospek masa depan ekonomi nasional sangat tergantung dari performa ekonomi dari dua partner dagang utama yakni Amerika Serikat dan Jepang, dan administrasi yang lebih terpercaya dan kebijakan pemerintah yang konsisten (Bradley dan Lubis: 1991: 79-83). Kepulauan Filipina dibagi menjadi tiga kelompok utama yaitu Luzon, Visayas, dan Mindanao. Sistem pemerintahan daerah Filipina dibagi menjadi hirarki satuan pemerintah lokal dengan provinsi sebagai satuan utama. Seluruh provinsi dikelompokkan menjadi 17 wilayah (region) untuk kemudahan administratif, dan kebanyakan kantor pemerintah daerah memiliki kantor Regional untuk melayani provinsi-provinsi di dalamnya. Wilayahwilayah di Filipina tidak memiliki pemerintahan lokal yang terpisah, kecuali Mindanao Muslim dan Wilayah Administratif Cordillera, yang memiliki otonomi khusus.
Filipina pernah mengalami masa kelam selama 21 tahun di bawah kepemimpinan pemerintahan otoriter Ferdinand Edralin Marcos. Tahun 1965 Marcos memenangkan Pemilu dan terpilih menjadi Presiden Filipina setelah mengalahkan Diosdado Macapagal. Ia dilantik menjadi Presiden Filipina yang ke10 pada 30 Desember 1965. Marcos berkuasa hingga 25 Februari 1986. Era kepemimpinan Marcos adalah era yang sangat kejam dan gelap bagi bangsa Filipina tatkala Marcos mulai mengeluarkan Undang-Undang Darurat Militer atau yang lebih umum dikenal dengan PD 1081 tahun 1972. Salah satu pasal UU tersebut mengatakan "Presiden Marcos telah menyelamatkan bangsa ini dari muslim fundamentalis yang hendak memisahkan diri, dan dari kebangkitan kembali komunis yang hendak meruntuhkan negara dan bangsa" (Alfuente, 1998: 66). UU Darurat sama seperti doktrin P4 di masa Orde Baru, di mana anak-anak sekolah diwajibkan menghapal pasal demi pasal UU tersebut. Namun di sisi lain, dengan menggunakan UU tersebut Marcos dapat menghabisi para musuh politiknya atau kalangan oposisi seperti yang dituduh Marcos kalangan sayap Kristen Demokrat, kalangan komunis, termasuk Ninoy Aquino, seorang mantan Wakil Gubernur dan seorang senator yang disegani (Kawilarang, 1984: 107-120).

Selain membuat UU Darurat, Marcos menggandeng militer dan birokrasi sebagai pendukungnya. Tahun 1981 menjelang pemilihan presiden UU Darurat Militer ditingkatkan statusnya menjadi UU Darurat Perang. Sehingga Marcos dapat kembali mencalonkan diri menjadi presiden. Ini artinya untuk keempat kalinya Marcos kembali mencalonkan diri menjadi presiden, padahal konstitusi Filipina hanya membolehkan seseorang mencalonkan diri selama 2 kali berturut-turut, 1 periode selama 6 tahun. Kemudian peranan Ibu Negara, Imelda Marcos yang lebih dikenal dengan sebutan "kupu-kupu besi" juga berperan bagi Marcos dalam membuat 
kebijakan politik. Selama pemberlakuan UU Darurat Militer dan Darurat Perang sejak tahun 1972 hingga kejatuhannya tahun 1986 diperkirakan mencapai 3000 orang yang hilang dan dibunuh. UU Darurat muncul sebagai bentuk ketakutan Marcos pada lawan-lawan politiknya akan menggantikan kekuasaannya. Dengan UU Darurat, Marcos hendak memperpanjang masa jabatan presidennya yang seharusnya mesti berakhir pada 1975 (Kawilarang, 1984: 117-118). Saat pemerintahan Marcos, Filipina belum memiliki perdana menteri.

Seperti halnya kejadian di Jakarta dalam menumbangkan Suharto dikenal istilah Reformasi 1998, di Filipina peristiwa penumbangan Marcos dikenal dengan Revolusi Edsa atau Revolusi Damai. Umumnya peristiwa tersebut juga disebut gerakan People Power, yakn karena jutaan rakyat Filipina tumpah ruah turun ke jalan berjalan dengan mengumandangkan pesan damai agar Marcos mau turun dari jabatannya dengan cara damai atau tidak menggunakan kekerasan.

Ada beberapa indikasi penyelewengan kekuasaan oleh Marcos selama pemerintahannya, dan ini pula menjadi ciri kepemimpinan Marcos. Pertama, korupsi yang merajalela di pemerintahan, diperkirakan kekayaan Marcos setelah tidak menjadi presiden mencapai US\$ 10 juta. Bahkan Ibu Negara, sang "kupu-kupu besi", dikenal dan diidentikkan dengan tiga sinonim kata yakni "kekayaan, keserakahan, dan kemewahan".

Kedua, militer memainkan peran kunci dalam pemerintahan Marcos. Jenderal Juan Enrile (Menteri Pertahanan Keamanan) dan Jenderal Fidel V. Ramos (Pimpinan Angkatan Bersenjata) merupakan dua sosok penting dalam pemerintahan yang kemudian ketika keduanya membelot dan berpihak kepada oposisi saat menjelang kejatuhan Marcos, maka kekuasaan Marcos menjadi rapuh. Hanya Jenderal Fabian Ver (Panglima Angkatan Bersenjata) yang tetap setia kepada Marcos walaupun akhirnya banyak pasukannya membelot kepada pihak oposisi.

Ketiga, terjadi penangkapan, pembunuhan, dan penculikan kalangan oposisi yang dicurigai mengancam pemerintahan. Marcos berdalih, mereka yang ditangkap, dibunuh dan diculik itu adalah antek komunis, kalangan kiri ekstrim dan kalangan fundamentalis yang hendak merusak negara. Bahkan kalangan aktivis yang berada di luar negeri seperti di Amerika pun tetap dimata-matai dan diculik oleh intel pemerintah Filipina yang dicurigai didukung FBI.

Keempat, pemerintahan Marcos didukung oleh Amerika Serikat di bawah pemerintahan Ronald Reagan, karena Marcos menyetujui adanya dua pangkalan militer AS di Filipina yakni Pangkalan Udara di lapangan terbang militer di Clark dan Pangkalan Angkatan Laut di Teluk Subic, yang memegang peran penting dalam menjaga pengaruh AS di Asia Tenggara. Pemerintahan Reagan juga meluluskan imbalan US\$ 900 juta kepada pemerintahan Marcos sebagai bentuk kompensasi perpanjangan kehadiran kedua pangkalan militer tersebut selama lima tahun.

Kelima, saat menjelang kajatuhan Marcos, Filipina mengalami krisis luar biasa, sebagai akibat korupsi dan pengelolan pemerintahan yang buruk. Bank-bank asing mulai tutup dan tidak mau memberikan pinjaman, dan pemerintahan Filipina agak menderita dengan larinya anggaran sebesar US\$ 200 juta untuk penanaman modal hanya dalam waktu satu bulan. Anggaran negara juga mengalami defisit antara US\$ 600 - US\$ 800 juta. Pemerintah juga memiliki utang sebesar US\$ 13 milyar untuk proyek-proyek jangka panjang, dan US\$ 4,5 milyar untuk proyek jangka pendek. Ekonomi negara secara keseluruhan mengalami kelumpuhan (Kawilarang, 1984: 117-118).

Paling tidak ada beberapa masalah yang dibuat Marcos sehingga rakyat Filipina tidak sabar menjatuhkannya, yaitu: 
Pertama, penangkapan dan pemenjaraan lawan politiknya masih bisa dimaklumi oleh rakyat Filipina. Namun pembunuhan terhadap Ninoy Aquino, seorang oposisi yang kritis, bekas wakil gubernur, dan seorang anggota senat yang vokal tidak dapat ditolerir lagi oleh rakyat Filipina. Sebelum mengalami pembunuhan, Ninoy dipenjara selama 7 tahun sebagai akibat pemberlakuan UU Darurat 1972. Ninoy orang pertama yang ditangkap saat pemberlakuan UU Darurat tersebut. Tidak puas memenjara Ninoy, pemerintahan Marcos membuang Ninoy ke pengasingan, tepatnya ke Hawai di AS selama 3 tahun. Setelah habis masa tahanannya, Ninoy pulang ke Manila, dan karena dikhawatirkan akan membuat agitasi politik melawan Marcos, Ninoy ditembak di bandara saat kedatangannya di Manila pada 21 Agustus 1983. Menariknya, orang yang dituduh membunuh Ninoy disebut antek komunis, ditembak tewas oleh tentara, lalu jenazahnya dibawa ke pengadilan dan disidangkan sebagai tersangka pembunuhan Ninoy. Jadi pengadilan pemerintahan Marcos menyidangkan dan mengadili mayat yang dituduh membunuh Ninoy. Selain Ninoy diperkirakan mencapai 3000 orang aktivis dan lawan politik Marcos yang ditangkap dan dibunuh selama pemerintahan Marcos (Soetomo, 1998: 3637).

Kedua, Pemilu Presiden 1981 pun dimanipulasi suaranya oleh Marcos. Demikian pula Pemilu 1986 yang diikuti Cory Aquino (istri mendiang Ninoy) sarat manipulasi oleh Marcos. Padahal rakyat Filipina tetap bersabar bahwa dengan mengikuti Pemilu dan mereka memilih Cory dengan harapan Cory menang, maka pergantian pemerintahan dapat dilakukan secara baik dan konstitusional. Namun karena dimanipulasi dan kemenangan Cory tidak terjadi, sebaliknya orang-orang pendukung Cory banyak ditangkap karena dituduh mengerahkan rakyat memilih Cory, maka kesabaran rakyat tidak terbendung.
Ketiga, pada 22 Februari 1986 Gerakan People Power, Revolusi Damai, atau Revolusi Edsa (karena dilakukan di Edsa, Quezon City, Manila) pun dimulai. Jenderal Juan Fidel Ramos (Menteri Pertanahan) dan Jenderal Fidel Ramos (seorang pimpinan Angkatan Bersenjata) bertempat di lantai 3 National Defense Building, Camp Aquinaldo, Edsa (Epifanio de los Santos Avenue) Quezon City, Manila, berbicara di depan wartawan TV, koran dan radio dan disiarkan secara langsung, yang mengemukakan bahwa mereka "tidak lagi mengakui Marcos sebagai pimpinan tertinggi angkatan bersenjata". Kedua jenderal ini juga meminta bantuan kepada Kardinal Sin, pimpinan gereja Katolik tertinggi di Filipina agar berdoa untuk mereka. Sin ternyata tidak sekadar berdoa, tetapi berbicara di Radio Veritas, satu-satunya media massa di Filipina yang tidak dibredel pemerintah karena bergerak di bawah tanah dan berada di bawah otoritas gereja Katolik. Sin berbicara agar rakyat Filipina berdoa untuk keselamatan negara dan perubahan yang akan sebentar lagi terjadi. Sin juga mengajak rakyat Filipina untuk turun secara damai untuk melindungi kedua jenderal itu dan camp tentara yang ada di Edsa dari kemungkinan serangan Marcos dan tentaranya.

Keempat, rakyat Filipina tumpah ruah ke jalan, jutaan jumlahnya dengan membawa perangkat sakral gereja seperti rosario, patung Yesus dan Bunda Maria, salib, dll, bahkan mereka melaksanakan Misa di Edsa dan di jalan-jalan. Warungwarung makan dan restoran yang dimiliki rakyat di sekitarnya memberi pasokan makanan, rumah-rumah memberi tumpangan kamar mandi, dan beristirahat, dll. Intinya seluruh rakyat Filipina bersatu, berdoa, dan berkumpul untuk perubahan menumbangkan Marcos.

Kelima, tidak ada pertumpahan darah saat itu, karena banyak tentara, polisi, tanktank perang, pesawat tempur, gas air mata, bahkan pasukan elit dan banyak jenderal yang dikirim Marcos ke Edsa justru tidak 
bertindak anarkis, mereka malah bergabung dengan rakyat. Marcos akhirnya dijemput dengan helikopter oleh tentara Amerika yang dikirim Presiden Reagan pada Selasa malam 25 Februari 1986, untuk selanjutnya diterbangkan dan diasingkan ke Honolulu, sampai akhir hayatnya. Seluruh keluarga Marcos terbang malam itu tanpa membawa apa-apa dari Istana Malacanang, mereka meninggalkan ribuan koleksi barang-barang mahal yang selanjutnya oleh rakyat Filipina dimasukkan ke dalam Museum. Di hari yang sama Cory Aquino dilantik menjadi Presiden Filipina ke-11 menggantikan Marcos.

Keenam, penyelewenangan pimpinan militer, peran sentral gereja, pemerintahan yang represif, kematian Ninoy, dan rakyat yang sudah tidak sabar karena sejak tahun 1972 diperintah secara diktator oleh Marcos, memegang peran penting bagi kejatuhan kekuasaan Marcos (Soetomo, 1998: 40-49).

\section{Praktik Demokrasi dan Politik Kontemporer}

Kabarnya, saat pelantikan Cory menjadi Presiden Filipina pada 25 Februari 1986 yang dihadiri jutaan rakyat Filipina pendukungnya, di tempat lain Marcos juga dilantik menjadi Presiden Filipina yang dihadiri 3000 orang yang dimobilisasi. Sementara di Indonesia, saat Suharto mengundurkan diri sebagai Presiden RI pada 21 Mei 1998, Wapres Habibie langsung dilantik menggantikannya dan terjadi penyerahan kekuasaan dari Suharto ke Habibie. Antara Marcos dengan Suharto ada perbedaan sikap atas pelengseran diri mereka. Perbedaan sikap tersebut dipastikan berdampak bagi perkembangan demokrasi pada kedua negara setelah mereka tidak lagi mengendalikan kekuasaan. Pasca Suharto (1998) dan pasca Marcos (1986), adalah hasrat bagi kedua negara mempraktikkan demokrasi. Namun justru pada titik inilah demokrasi dipakai hanya semata-mata sebagai retorika pelegitimasian.
Buktinya, hanya dua tahun setelah Cory memerintah, muncul tindakan kudeta oleh seorang jenderal angkatan bersenjata sisa pengikut Marcos, dan setelah Jenderal Ramos menjadi Presiden menggantikan Corry tahun 1996 muncul keinginan Ramos untuk merevisi konstitusi dengan tujuan memperpanjang masa jabatannya sebagai presiden. Di Indonesia, selang setahun masa pemerintahan Habibie, pidato pertanggungjawabannya ditolak DPR sehingga ia tidak berniat lagi mencalon menjadi presiden pada Pemilu 1999. Tahun 2001, Presiden Abdurrahman Wahid diimpeach oleh DPR setelah setahun lebih berkuasa, di mana Megawati naik jabatan dari semula Wakil Presiden menjadi Presiden RI sampai 2004. Pada masa pemerintahan Megawati, ia sudah berevolusi menjadi pemimpin kharismatik yang memihak pada penegakan demokrasi dalam konteks sikap politiknya, di mana Megawati menghendaki penegakan hukum, HAM, kebebasan pers, penghapusan Dwifungsi ABRI, bahkan komitmen pemberantasan korupsi dengan pembentukan Komisi Pemberantasan Korupsi (KPK) tahun 2002 (Denny J.A: 1999: 187-191; Sembiring, 2015).

Namun dalam pemerintahan baru yang diagungkan sejak Habibie sampai Jokowi sekarang korupsi tidak juga hilang di Indonesia, walau beberapa cita-cita lainnya sudah terwujud seperti kebebasan pers dan penghapusan Dwifungsi ABRI. Di Filipina, krisis ekonomi masih tetap berlangsung dalam pemerintahan Cory, sampai tahun 1988-1989 terjadi krisis air bersih, sampaisampai orang pulang kerja di sore hari terus berpikir nanti sampai di rumah bagaimana bisa mandi dan minum air putih (Alfuente, 1998: 122-128). "Pesta Demokrasi" yang menjamin mayoritas, yang menobatkan baik Habibie dan Abdurrahman Wahid di Indonesia maupun Corry Aquino di Filipina menjadi presiden, menggambarkan bahwa demokrasi bukan jaminan bagi perbaikan pemerintahan dan ekonomi, karena elit dan orang yang bekerja di situ tetap orang- 
orang lama yang memiliki ikatan emosional dengan rezim lama.

Kalaupun semua tuntutan untuk pemilihan "jurdil" terpenuhi, hal itu belum juga menjamin sebuah demokrasi yang memadai. Pola keterlibatan rakyat yang terbatas pada pemilihan pemimpin disebut Max Weber sebagai "plebiscitary leadership democracy" (Held, 1987: 158). Di mana rakyat boleh memilih diantara sekelompok elit politik untuk memerintah atas mereka, lalu setelahnya rakyat diharapkan berdiam diri dan ikut-ikutan saja sampai pemilu berikutnya. Keterlibatan rakyat dalam demokrasi terbatas pada sekali tusuk kertas suara setiap satu periode pemerintahan. Dalam pandangan Weber pola ini berfungsi terutama untuk menjamin suksesi kepemimpinan secara teratur (pemilu lebih baik dari coup d'etat, misalnya), dan hanya secara sekunder (dan periodik) untuk menyatakan kehendak rakyat. Karena calon-calon terambil dari kelompok elit politik yang mempunyai latar belakang dan kepentingan yang tidak jauh berbeda, maka sebuah pemilu dengan sendirinya jarang menghasilkan perubahan yang signifikan dalam arah kebijakan publik. Pemantauan terhadap sejumlah Pemilu dan Pilkada pasca reformasi membenarkan pandangan Weber. Pertimbangan para pemilih sering terbatas pada "figur" atau "sosok pemimpin" yang disukai (selain pertimbangan etnis atau agama). Jarang ada perhatian pada program atau gagasan yang dikemukakan para calon.

Aspek lain dari demokrasi yang terjadi hingga hari ini di kedua negara ialah bahwa sebagai negara demokratis baru, setiap rujukan konsep demokrasi dan turunan nilai-nilainya, digantungkan kepada negara demokrasi tua yaitu Amerika. Filipina sepeninggal Marcos hingga hari ini merupakan sekutu Amerika dan sekaligus juga menjadi anggota Gerakan Non-Blok. Sedangkan Indonesia sepeninggal Suharto walaupun berada dalam blok yang sama dengan Filipina namun bukan merupakan sekutu Amerika. Strategi yang dilakukan
Filipina untuk mewujudkan pembangunan politik yang matang ialah melalui peningkatan pembangunan infrastruktur juga dilakukan pemerintahan Jokowi belakangan di Indonesia. Sama seperti Filipina, Indonesia juga merombak sistem pajak untuk menambah pendapatan pemerintah, deregulasi dan penswastaan ekonomi, serta meningkatkan integrasi perdagangan di wilayah sekitar masingmasing.

Prospek masa depan Filipina sangat tergantung dari performa ekonomi dari dua partner dagang utamanya yaitu Amerika Serikat dan Jepang, dengan terus menata iklim administrasi yang terpercaya dan kebijakan pemerintah yang konsisten mendorong pertumbuhan ekonomi. Di Indonesia, sejak masa pemerintahan SBY, Amerika masih merupakan mitra dagang utama, namun pada masa Jokowi sejak 2014 mulai beralih ke Tiongkok bahkan dengan menyediakan lapangan kerja lokal bagi pekerja dari Tiongkok. Filipina bersengketa dengan Republik Cina (Taiwan), RRC (Tiongkok), Vietnam dan Malaysia atas minyak dan gas alam di Kepulauan Spratly dan Scarborough Shoa dan dengan Malaysia atas Sabah. Namun Indonesia lebih memilih bekerjasama dengan Filipina menangani kelompok pembajak laut di wilayah perbatasan selat Karimata dan selat Sulawesi.

Sejauh ini, baik Indonesia maupun Filipina sama-sama mempraktikkan konsep demokrasi dari Amerika Serikat yang malah di dalamnya muncul banyak masalah. Demokrasi memasukkan prinsip good governance guna modernisasi administrasi dan birokrasi pemerintahan, namun juga disertai masuknya intervensi Amerika. Di Filipina, melalui Presiden Duterte, Amerika adalah pemasok senjata dengan alasan untuk menumpas teroris, yang belakangan mulai beralih membeli senjata dari Rusia. Sedangkan Indonesia sudah sejak lama beli peralatan senjata dari Rusia, terutama pesawat tempur sejak masa pemerintahan Megawati, dan pada masa pemerintahan 
SBY tahun 2009 Indonesia lebih banyak dibantu Amerika terutama terkait pengadaan logistik (IT) pemilu.

Namun demikian, kedua negara masih memiliki tugas besar terkait pemberantasan korupsi. Presiden Arroyo setelah melepas masa jabatannya tahun 2010 bersama 10 mantan pejabat negara lainnya dituduh korupsi penyalahgunaan dana lotere milik negara dan melakukan korupsi terkait pembatalan kontrak broadband nasional senilai 329 juta dollar Amerika dengan perusahaan asal Cina ZTE pada tahun 2007 (Rubrik, 2012). Sedangkan di Indonesia, banyak elit politik lokal maupun nasional mulai bupati, walikota, gubernur, menteri, pejabat partai politik, anggota DPR dan DPRD, hakim, jaksa, polisi, pengusaha dan pejabat negara lainnya masuk penjara ditangani KPK karena melakukan korupsi merugikan negara. Oligarki politik seperti disebutkan terdahulu juga menjadi tantangan besar bagi kedua negara dalam menegakkan demokrasi. Kendati mekanisme pemilihan pemimpin pemerintahan dan politik dilaksanakan secara terbuka dan demokrasi, namun tetap saja kelompok oligark baik di pusat maupun di daerah dapat masuk dan mengendalikan pemerintahan. Korupsi maupun oligarki politik yang menguasai ekonomi dan politik dalam negeri kedua negara merupakan warisan rezim otoriter masa lalu. Kalau di Filipina dapat dihitung 170 dinasti politik dan hampir 90\% provinsi memiliki satu dinasti politik, maka di Indonesia dapat dikatakan hampir semua daerah memiliki dinasti politik, baik dalam ranah pemerintahan daerah, partai politik, sektor ekonomi, dan pemerintah pusat.

Kedua negara mesti mencari dan menemukan solusi untuk mengurangi fenomena korupsi dan oligarki politik ini, yakni melalui pendidikan karakter anti korupsi sejak usia anak sekolah di sekolah-sekolah sampai perguruan tinggi, penegakan hukum yang tegas dan setimpal dengan kesalahan, konsisten melarang mantan narapidana korupsi terlibat dicalonkan dalam pemilu, pilkada dan pilpres bahkan bila perlu dicabut hak politiknya, menegakkan aturan pemilu secara konsisten yakni melarang anggota oligarki sebagai calon kepala daerah, anggota legislatif dan calon presiden-wakil presiden.

\section{KESIMPULAN}

Pertama, tumbangnya rezim otoriter di Filipina dan Indonesia memang membawa sisi baik bagi pengembangan demokrasi kedua negara, kendati belum menyelesaikan masalah secara signifikan. Pengembangan demokrasi tidak cukup dengan pembangunan politik atau usahausaha serupa ke arah implementasi good governance. Fakta adanya aliansi oligarki politik dan ekonomi di pusat dan daerah pada pemerintahan kedua negara menunjukkan perlu ada upaya yang sejajar untuk membatasi dan mengimbangi pengaruh kelompok-kelompok tersebut, terutama di sekitar aspek ekonomi, keamanan, budaya, dan (mungkin juga) agama, antara lain seperti perlu mendorong regenerasi kepemimpinan dalam setiap level pemerintahan, pembatasan usia minimal dan maksimal pemimpin politik, dan pemberantasan korupsi.

Kedua, trauma yang masih tersisa dari riwayat jauhnya peran rezim otoriter dalam politik masa lalu menuntut upaya-upaya pendamaian, pencarian kebenaran, peradilan untuk menghapus impunitas, reparasi dan rekonsiliasi. Mengatur kehidupan bersama secara demokratis mengasumsikan sebuah kerelaan untuk hidup bersama, dan untuk itu rekonsiliasi menjadi prasyarat. Itulah sebabnya untuk kasus Filipina, baik Aquino junior yang menjadi presiden sampai tahun 2016 maupun Marcos junior dan Imelda Marcos yang duduk di Senat nampak ingin melupakan peristiwa masa lalu mereka, dan sama-sama lebih berkonsentrasi membangun bangsa dan negara. Hal yang berbeda di Indonesia di mana masih terjadi saling curiga sesama anak bangsa, bahkan Presiden Jokowi sendiri sering menjadi sasaran fitnah warga negaranya sendiri maupun lawan-lawan politiknya. Belum ada kesepakatan bersama diantara pemimpin 
bangsa dan segenap elemen bangsa saat ini tentang pembangunan politik negara, yang ada adalah saling adu domba, menghujat, fitnah, penyebaran kabar bohong yang tidak terkendali. Indonesia tertinggal satu langkah dengan Filipina dalam hal konsolidasi politik ini.

Ketiga, mencari satu model demokrasi yang benar sesuai karakter sebuah bangsa dan negara adalah sama sulit dengan mencari satu model agama yang benar. Dalam masyarakat yang pluralistis, cita-cita terhadap demokrasi menjadi pluralistis juga. Berbagai pihak dalam masyarakat akan memperjuangkan jenis-jenis demokrasi yang berbeda-beda. Hanya melalui dialog dan negosiasi dalam perjalanan bersama akan lahir sebuah "demokrasi pribumi" dan terukir dalam pergumulan bersama seluruh elemen masyarakat. Lebih baik melihat demokrasi sebagai sebuah proses daripada sebuah

\section{Daftar Pustaka}

Alfuente, Rhian Salome Tuzon. 1998. "Revolusi Edsa untuk Indonesia sekarang ini: Umpan Balik dari Filipina", Prolog dalam Greg. Soetomo. Revolusi Damai, Belajar dari Filipina. Yogyakarta: Kanisius.

Bradley, William L., dan Mohtar Lubis. 1991. Dokumen-Dokumen Pilihan Tentang Politik Luar Negeri Amerika dan Asia. Jakarta: Yayasan Obor Indonesia.

Bourchier, David. 2010. "Kisah Adat Dalam Imajinasi Politik Indonesia dan Kebangkitan Masa Kini", dalam Jamie S. Davidson, David Henley dan Sandra Moniaga (Ed.). Adat Dalam Politik Indonesia. Jakarta: Yayasan Obor Indonesia dan KITLV-Jakarta.

Campbell-Nelson, John. "Beberapa Catatan tentang Gereja dan Politik", Makalah, bahan diskusi dalam Konsultasi Gereja dan Politik Pasca Orde Baru, Makassar, Yayasan Oase INTIM, 12 Februari 2012. ideologi atau filsafat. Maka, unsur-unsur mana yang menyerupai proses demokrasi itu menjadi fokus dari upaya membangunnya.

Terakhir, demokrasi tidak hidup dalam isolasi dari dunia yang luas. Praktik demokrasi di negara-negara lain tidak perlu menjadi tolok ukur untuk demokrasi di Indonesia ataupun Filipina, tapi Indonesia dan Filipina juga tidak bisa melepaskan diri dari interaksi dengan ide-ide, nilai-nilai, dan kepentingan-kepentingan bangsa-bangsa lain. Cara menjaga demokrasi agar tetap hidup dan dipercaya sebagai jalan terbaik mengelola negara ialah dengan menghadirkan kesejahteraan bagi warga negara, keamanan terjamin, hubungan pusat dan daerah yang adil, penegakan hukum dan kepemimpinan pemerintahan kuat yang berpihak kepada kepentingan seluruh elemen bangsa.

Eko, Sutoro. 2003. Transisi Demokrasi Indonesia: Runtuhnya Rezim Orde Baru. Yogyakarta: APMD Press.

Hargens, Boni. "Kebutuhan Demokrasi Lokal”, Media Indonesia, 8 Oktober 2009.

Held, David. 1987. Models of Democracy. Stanford: Stanford University Press. . 1995. Democracy and the Global Order: From the Modern State to Cosmopolitan Governance. Stanford: Stanford University Press.

Hikam, Mahammad A.S., 1999. Politik Kewarganegaraan, Landasan Redemokratisasi di Indonesia. Jakarta: Erlangga.

Imawan, Riswandha. 2000. "Reformasi Politik dan Demokratisasi Bangsa", dalam Selo Soemardjan (Ed.). Menuju Tata Indonesia Baru. Jakarta: Gramedia Pustaka Utama.

J. A. Denny. 1999. "Mengamati Megawati", dalam Musa Kahzim dan Alfian Hamzah 
(Ed.). 5 Partai Dalam Timbangan. Bandung: Pustaka Hidayah.

Kawilarang, Harry. 1984. "Filipina Sepeninggal Ninoy", dalam Dunia di Tengah Kemelut: Bunga Rampai Masalah Internasional. Jakarta: UI Press. Klinken, Gerry van.. 2010. "Kembalinya Para Sultan: Pentas Gerakan Komunitarian Dalam Politik Lokal", dalam Jamie S. Davidson dkk. (Peny.). Adat Dalam Politik Indonesia. Jakarta: Buku Obor dan KITLV-Jakarta.

Liddle, William. 1999. "Regim: The New Order" dalam Donald K. Emmerson (Ed.). Indonesia Beyond Suharto: Polity, Economy, Society, Transition. New York: M. E. Sharpe, Inc dan the Asia Society.

Mas'oed, Mochtar. 1989. Ekonomi dan Struktur Politik Orde Baru 1966-1971. Jakarta: LP3ES.

O’Donnell, Guillermo, Philippe C. Schmitter, dan Laurance Whitehead (Ed.). 1993. Transisi Menuju Demokrasi: Tinjauan Berbagai Perspektif. Jakarta: LP3ES.

Philpott, Simon. 2003. Meruntuhkan Indonesia: Politik Postkolonial dan Otoritarianisme. Yogyakarta: LKiS.

Purwaningsih, Titin. 2015. "Politik Kekerabatan Dalam Politik Lokal di Sulawesi Selatan Pada Era Reformasi: Studi Tentang Rekrutmen Politik Pada Partai Golkar, Partai Amanat Nasional dan Partai Demokrat Sulawesi Selatan tahun 2009". Disertasi Ilmu Politik, FISIP Universitas Indonesia.

Sahdan, Gregorius. 2004. Jalan Transisi Demokrasi Pasca Suharto. Yogyakarta: Pondok Edukasi.

Sembiring, Eidi Krina Jason. "Mengingat Kembali Kelahiran KPK", dalam Sindonewscom, 20 Agustus 2015.

Soetomo, Greg. 1998. Revolusi Damai: Belajar dari Filipina. Yogyakarta: Kanisius.

Somantri, Gumilar Rusliwa. "Memahami Metode Kualitatif", dalam Jurnal Sosial Humaniora "Makara", Volume IX (2) Desember, 2005.

Sompa, Andi Tenri. 2016. “Penguasa Lokal dan Bisnis Tambang Batubara : Studi Kasus Hubungan Pemerintah Daerah dengan Pebisnis Tambang Batubara Dalam Dinamika Politik Lokal di Kabupaten Tanah Bumbu Provinsi Kalimantan Selatan (2009-2013)". Disertasi Ilmu Politik, FISIP, Universitas Indonesia.

Steni, Bernidus. 2012. "Tragedi Pertambangan dan dan Gereja yang Aksional", dalam Rikard Rahmad (Ed.). Gereja Itu Politis: Dari Manggarai-Flores untuk Indonesia. Jakarta: JPIC.

Supriatma, A. Made Tony. "Menguatnya Kartel Politik Para "Bos"”, dalam Prisma Vol. 28, No. 2, Oktober 2009. 